\section{Inheritance of Style Color in Hazelnut}

Shawn A. Mehlenbacher ${ }^{1}$ and Maxine M. Thompson

Department of Horticulture, Oregon State University, 4017 Agricultural and Life Sciences Building, Corvallis, OR 97331

Additional index words. Corylus avellana, filbert, nut breeding, anthocyanin

Abstract. The style color of standard hazelnut (Corylus avellana L.) cultivars ranges from pink to dark purple. Styles with an unusual yellow color were first noted in seedlings of the progeny 'Goodpasture' $x$ 'Compton', and the ratio was $\approx 3$ red : 1 yellow. Controlled crosses were made to investigate the genetic control of style color. The same 3:1 ratio was observed in four additional crosses in which both parents had red styles. Two crosses of a red and a yellow parent gave $\approx \mathbf{5 0 \%}$ yellow styles, while a cross of two selections with yellow styles gave only seedlings with yellow styles. These segregation ratios indicate control by a single locus, with yellow style color recessive to red. Seedlings with yellow styles have green buds and catkins and a more upright growth habit than their siblings with red styles. Inspection of the pedigrees of these progenies shows that 'Daviana', 'Willamette', 'Butler', 'Compton', 'Goodpasture', and 'Lansing \#1' are heterozygous. 'Daviana' appears to be the original source of the allele for yellow styles, as it is a known or suspected parent or ancestor of the others. Ratios in a progeny segregating simultaneously for growth habit (normal vs. contorted) and style color indicated independence of the traits. However, in a progeny segregating simultaneously for leaf color (red vs. green) and style color, no redleaf seedlings had yellow styles. The $S$-alleles of eight genotypes with yellow styles were determined, and indicate a possible linkage between the yellow style locus and the $S$ locus that controls pollen-stigma incompatibility. One explanation is that the yellow style trait is conferred by an allele $\left(a^{y s}\right)$ at the anthocyanin $(A)$ locus that controls leaf color. A second explanation is that there is a yellow style locus closely linked to the $A$ locus. The $A$ locus is known to be loosely linked to the $S$ locus.

The European hazelnut (Corylus avellana L.) is a monoecious, wind-pollinated shrub that enforces cross-pollination through dichogamy and self-incompatibility. The style color of standard green-leafed hazelnut cultivars ranges from pink to dark purple. Only when branches are bagged to protect female inflorescences from wind-borne pollen do the styles continue to elongate and the color fades from red or pink to light yellow or white. In 1978, in the progeny 'Goodpasture' $x$ 'Compton', styles with an unusual yellow color (Fig. 1) were noted in $\approx 25 \%$ of the seedlings. The yellow color was present when the styles first emerged and persisted as the flowers aged. We report here the results of an investigation of the genetic control of style color in hazelnut.

\section{Materials and Methods}

Controlled pollinations were performed over a period of several years as part of a hazelnut breeding program at Oregon State University using standard practices, including emasculation followed by bagging individual limbs or covering the entire tree with a wooden frame covered with white polyethylene (Thompson et al., 1996). Pollen was collected and stored in the freezer and compatibility of crosses was verified and S-alleles identified using fluorescence microscopy (Mehlenbacher, 1997). Selections with yellow styles were crossed with 'Purple Aveline', 'Rode Zeller', 'Redleaf \#3', C. $a$. Received for publication 16 Apr. 2003. Accepted for publication 29 June 2003. A Technical Paper of the OregonAgricultural Experiment Station. This research was supported with funds from the Oregon Hazelnut Commission. We thank David C. Smith for technical assistance.

'E-mail nmehlenbs@science.oregonstate.edu.

HortScience Vol. 39(3) June 2004 are heterozygous. Crosses in which one parent had red styles and the other yellow segregated $\approx 50 \%$ yellow, although progeny 97052 showed a deficiency of yellow styles. A cross of two selections with yellow styles gave only seedlings with yellow styles. These ratios indicate control by a single locus at which the allele for yellow style color is recessive.

Otherphenotypic differences were seen. The leaf buds and catkins of seedlings with yellow styles are bright green, as they lack the traces of anthocyanin present on these plant parts in their siblings with red styles. Seedlings with yellow styles also have a more upright growth habit than their siblings with red styles.

Inspection of the pedigrees of these progenies (Table 2) shows that 'Daviana', 'Willamette', 'Butler', 'Compton', 'Goodpasture', and 'Lansing\#1' are heterozygous. These last fourcultivars were selected by hazelnut growers in Oregon and are believed to be hybrids between 'Barcelona', Oregon's leading cultivar, and 'Daviana', its most common pollenizer. Seedlings with yellow styles were observed in the cross $525.085 \mathrm{x}$ 'Daviana'. As 'Daviana' is an ancestor of 525.085, and is believed to be a parent or ancestor of the other heterozygotes, it appears to be the original source of the allele for yellow styles.

Contorted growth habit is conferred by a recessive allele ( $t w$ ) (Smith and Mehlenbacher, 1996). The progeny that segregated simultaneously for growth habit and style color (Table 3 ) fit a 9:3:3:1 ratio, and the contingency chi-share $\left(\chi^{2}=0.02, P=0.89\right)$ indicated independence of the two loci.

Thompson (1985) showed that crosses of the red-leaved cultivars 'Rode Zeller' and $C$. pedigrees (Table 2). Controlled pollinations were made in February and hybrid seeds were harvested in August. The seeds were stratified for 3 to 5 months and sprouted seeds were planted in flats in the greenhouse. When $\approx 20$ $\mathrm{cm}$ tall the seedlings were transplanted to $3.8-\mathrm{L}$ pots and grown in the greenhouse during the summer. The seedlings were moved outside in September and hardened for one month, then planted in the field in October. Style color was noted as the shrubs began to flower, generally 5 to 6 years after planting in the field.

Chi-square goodness-of-fit tests were performed for expected ratios of red : yellow styles of $3: 1$ or $1: 1$. A progeny segregating simultaneously for growth habit (normal vs. contorted) and style color was tested separately for each trait, and for a combined ratio of 9:3:3:1. A progeny segregating simultaneously for leaf anthocyanin (red vs. green color) and style color was also tested separately for each trait, and for a combined ratio of $2: 1: 1$. Contingency chi-square tests were used to detect deviations from expectations based on independent assortment at two loci. The Yates correction factor was not used.

\section{Results and Discussion}

When selections with yellow styles were crossed with 'Purple Aveline', 'Rode Zeller', 'Redleaf \#3', C. a. var. aurea, and the cutleaf hazelnut, all resulting seedlings had red styles (data not shown). In five progenies from crosses of parents with red styles, $\approx 25 \%$ of the seedlings had yellow styles (Table 1), indicating that the trait is recessive and that these parents

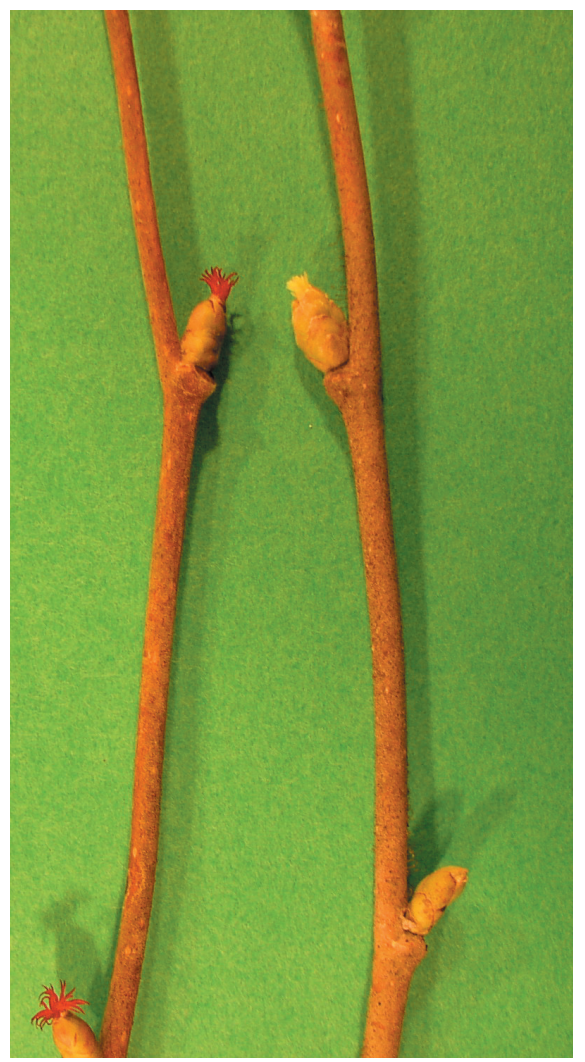

Fig. 1. Hazelnut female inflorescences with red (left) and yellow (right) styles. 
Breeding, Cultivars, Rootstocks, and Germplasm Resources

Table 1. Segregation for style color in hazelnut progenies.

\begin{tabular}{|c|c|c|c|c|c|}
\hline \multirow[b]{2}{*}{ Progeny } & \multirow[b]{2}{*}{ Parents } & \multicolumn{2}{|c|}{ Style color } & \multirow[b]{2}{*}{$\chi^{2}$} & \multirow[b]{2}{*}{$P$} \\
\hline & & $\overline{\text { Red }}$ & Yellow & & \\
\hline \multicolumn{6}{|c|}{ Progenies segregating $3: 1$} \\
\hline 72049 & 'Goodpasture' x 'Compton' & 113 & 34 & 0.27 & 0.60 \\
\hline 81036 & $13.013 \times 68.073$ & 50 & 11 & 1.58 & 0.21 \\
\hline 81062 & $33.113 \times 67.026$ & 15 & 5 & 0.00 & 1.00 \\
\hline 81063 & 33.113 x 'Willamette' & 21 & 12 & 2.27 & 0.13 \\
\hline \multirow[t]{3}{*}{97055} & 525.085 x 'Daviana' & 47 & 13 & 0.36 & 0.55 \\
\hline & Pooled data (5 progenies) & 246 & 75 & 0.46 & 0.50 \\
\hline & Heterogeneity & & & 4.02 & 0.40 \\
\hline \multicolumn{6}{|c|}{ Progenies segregating 1:1 } \\
\hline 88145 & $233.101^{y} \times 234.025$ & 12 & 18 & 1.20 & 0.27 \\
\hline \multirow{3}{*}{97052} & $525.085 \times 30.013^{y}$ & 42 & 25 & 4.31 & 0.04 \\
\hline & Pooled data ( 2 progenies) & 54 & 43 & 1.25 & 0.26 \\
\hline & Heterogeneity & & & 4.26 & 0.04 \\
\hline
\end{tabular}

$\frac{94027}{{ }^{2} \text { Seedlings with no females were excluded(43 seedlings in progeny } 72049,2 \text { in 88145, and 1 each in 81036, }}$ 81062, and 81063).

ySelection with yellow styles.

a. fusco-rubra with green-leaved selections segregated 1 red : 1 green, indicating control by a single leaf anthocyanin locus which she designated $A$. She also proposed a second locus for leaf color $(C)$ linked to the $A$ and $S$ loci in interspecific crosses, but a single locus was sufficient to explain segregation in crosses within C. avellana. In the progeny that segregated simultaneously for leaf color and style color (Table 4), no seedlings with red leaves and yellow styles were recovered, for which we offer two explanations. The first hypothesis is that there are three alleles at the anthocyanin locus ( $A, a$, and $\left.a^{\mathrm{ys}}\right)$ which show a dominance hierarchy $\left(A>a>a^{\mathrm{ys}}\right)$. Trees that carry the $A$ allele have much anthocyanin in styles, leaves, and catkins. Trees that are homozygous $a^{\mathrm{ys}} a^{\mathrm{ys}}$ have green leaves and yellow styles, and trees homozygous $(a a)$ or heterozygous $\left(a a^{\mathrm{ys}}\right)$ for the wild-type allele $(a)$ have red styles and traces of anthocyanin in leaves and catkins. The redleaved parent trees 452.109 and 452.120 would be heterozygous $\left(A a^{\mathrm{ys}}\right)$, as their female parent has yellow styles. From crosses of these two selections with $525.085\left(a a^{\mathrm{ys}}\right)$, a phenotypic segregation ratio of 2 red leaves and red styles $\left(A a\right.$ and $\left.A a^{\mathrm{ys}}\right): 1$ green leaves and red styles $(a$ $\left.a^{\mathrm{ys}}\right): 1$ green leaves and yellow styles $\left(a^{\mathrm{ys}} a^{\mathrm{ys}}\right)$

would be expected. An alternate hypothesis is that there are two closely linked loci, $A$ that controls leaf color and $Y s$ that controls style color, and that we failed to recover seedlings with red leaves and yellow styles because of the small population size. Recovery of seedlings with red leaves and yellow styles in a larger population would rule out the first hypothesis.

The incompatibility alleles of 8 selections with yellow styles (OSU 233.101, 233.106, 234.019, 246.128, 246.148, 372.087, 732.109, and 732.114) were identified using fluorescence microscopy. OSU 372.087 was $\mathrm{S}_{1} \mathrm{~S}_{11}, 732.109$ was $\mathrm{S}_{3} \mathrm{~S}_{11}$, and 732.114 was $\mathrm{S}_{1} \mathrm{~S}_{1}$, while the other five were $S_{1} S_{3}$. 'Daviana' is $S_{3} S_{11}$ (Thompson, 1979). The small number of alleles (three) in these selections is partly a function of the inbreeding needed to recover recessive homozygotes, but also suggests a possible loose linkage between the $y s$ and incompatibility $(S)$ loci. Thompson (1985) presented evidence that the anthocyanin locus $(A)$ and the incompatibility locus $(S)$ were linked. If the presence of anthocyanin in leaves and styles is the result of action of different alleles at a single locus, or two closely linked loci, then linkage to the $S$ locus would be expected. The identification of $\mathrm{S}$-alleles in seedlings in a progeny segregating
Table 2. Pedigrees of selections. Selections with yellow styles are indicated in bold. Heterozygous selections are indicated in italics.

\section{Selection Parents}

$13.013 \quad$ Barcelona $\times$ Lansing

26.122 Goodpasture x Compton

26.126 Goodpasture $\times$ Compton

30.009 Goodpasture $\times$ Compton

30.013 Goodpasture $\times$ Compton

33.113 Lansing o.p.

$67.026 \quad 14.019 \times 17.068$

$14.019=$ Barcelona $\times$ Butler

$17.068=$ Barcelona $\times$ Tombul Ghiaghl

$68.073 \quad 14.019 \times 17.068$

$233.007 \quad 13.013 \times$ Henneman \#3

233.101 $13.013 \times 68.073$

233.106 $13.013 \times 68.073$

$\mathbf{2 3 4 . 0 1 9} 13.013 \times 68.073$

$234.02513 .013 \times 68.073$

$\mathbf{2 4 6 . 1 2 8} 33.113 \times$ Willamette

246.148 $33.113 \times$ Willamette

$372.087 \quad 26.122 \times 26.126$

$452.109 \quad \mathbf{3 0 . 0 1 3} \times$ Rode Zeller

$452.120 \quad \mathbf{3 0 . 0 1 3} \times$ Rode Zeller

$486.060 \quad \mathbf{2 4 6 . 1 2 8} \times$ Contorta

$486.062 \quad \mathbf{2 4 6 . 1 2 8} \times$ Contorta

$525.085 \quad 233.007 \times \mathbf{2 4 6 . 1 2 8}$

$\mathbf{7 3 2 . 1 0 9} \quad 372.087 \times 246.128$

$\mathbf{7 3 2 . 1 1 4} 372.087 \times \mathbf{2 4 6 . 1 2 8}$

$\mathbf{8 9 9 . 0 1 0} 525.085 \times 452.120$

$899.036525 .085 \times$ Daviana

$\mathbf{9 0 0 . 0 1 0} 525.085 \times \mathbf{3 0 . 0 1 3}$

for style color would confirm the existence of separate but linked ys and $S$ loci.

\section{Literature Cited}

Mehlenbacher, S.A. 1997. Testing incompatibility of hazelnut crosses using fluorescence microscopy. Acta Hort. 445:167-171.

Smith,D.C. and S.A. Mehlenbacher. 1996. Inheritance of contorted growth habit in hazelnut. Euphytica 89:211-213.

Thompson, M.M. 1979. Incompatibility alleles in Corylus avellana L. cultivars. Theor. Appl. Genet. 55:29-33.

Thompson, M.M. 1985.Linkage of the incompatibility locus and red pigmentation genes in hazelnut. $\mathrm{J}$. Hered. 76:119-122.

Thompson, M.M., H.B. Lagerstedt, and S.A. Mehlenbacher. 1996. Hazelnuts, p.125-184. In: J. Janick and J.N. Moore (eds.). Fruit breeding. vol. 3. Nuts. Wiley, New York.

Table 3. Simultaneous segregation for growth habit and style color. ${ }^{2}$

\begin{tabular}{|c|c|c|c|c|c|c|c|c|c|c|c|}
\hline \multirow[b]{3}{*}{ Progeny } & \multirow[b]{3}{*}{ Parents } & \multicolumn{10}{|c|}{ Growth habit } \\
\hline & & \multicolumn{2}{|c|}{ Normal } & \multicolumn{2}{|c|}{ Contorted } & \multicolumn{2}{|c|}{ 3:1 Style } & \multicolumn{2}{|c|}{ 3:1 Growth } & \multicolumn{2}{|c|}{$9: 3: 3: 1$} \\
\hline & & Red & Yellow & Red & Yellow & Value & $P$ & Value & $P$ & Value & $P$ \\
\hline
\end{tabular}

Seedlings with no female inflorescences (four with normal and seven with contorted growth habit) were excluded in the calculation of chi-square test statistics. If these are included, the test statistic for fit to a 3:1 ratio for growth habit is 0.005 and $0.9<P<0.95$.

Table 4. Simultaneous segregation for leaf color and style color.

\begin{tabular}{|c|c|c|c|c|c|c|c|}
\hline \multirow{4}{*}{ Progeny } & \multirow{4}{*}{ Parents } & \multicolumn{6}{|c|}{$\chi^{2}$} \\
\hline & & \multicolumn{4}{|c|}{ Leaf color } & & \\
\hline & & \multicolumn{2}{|c|}{ Red } & \multicolumn{2}{|c|}{ Green } & & \\
\hline & & \multicolumn{4}{|c|}{ Style color } & \multicolumn{2}{|c|}{$\chi^{2}\left(2: 1: 1^{z}\right)$} \\
\hline 97053 & $525.085\left(a a^{y s}\right) \times 452.109\left(A a^{y s}\right)$ & 41 & 0 & 20 & 14 & 1.61 & 0.45 \\
\hline 97054 & $525.085\left(a a^{y s}\right) \times 452.120\left(A a^{y s}\right)$ & 17 & 0 & 8 & 6 & 0.55 & 0.76 \\
\hline Pooled c & & 58 & 0 & 28 & 20 & 2.15 & 0.34 \\
\hline
\end{tabular}

${ }^{2}$ Ratio expected if red leaves and red styles are controlled by different alleles $\left(A, a\right.$, and $\left.a^{y s}\right)$ at a single anthocyanin locus. Control by two tightly linked loci $(A$ and $Y s$ ) would give the same expected ratio. 